\title{
Impresiones sobre algunos teatros miraflorinos de Lima
}

\section{Gabriel Catalan}

Los turistas visitan museos, sitios arqueológicos, monumentos históricos, exposiciones, tiendas, restaurantes, parques, librerías, calles y por supuesto el centro de una ciudad, pero hay también mucho de aprender sobre la vida cultural de la capital de un país si van al teatro.

Yo me acostumbré a hacerlo. Por eso, estando en Miraflores, el barrio bonito de Lima donde vivo ahora, decidí irme a varios espectáculos teatrales. Hasta ahora he ido a tres teatros distintos y puedo confesar sinceramente que me gustaron todos a pesar de las grandes diferencias de géneros y estilos abordados. Me pareció que la fuente de la inspiración artística peruana, especialmente cuando se eligen las obras, es ciertamente vinculada a la moda europea y norteamericana, cosa que no puede ser menos que laudable.

Debo especificar que no se pueden comparar las obras; por eso mi texto no va a establecer ninguna preferencia y su estructura tiene más que ver con la cronología e historia de los personajes de las obras.

Primero voy a mencionar la obra Drácula, inspirada de la clásica novela horror del año 1897 del irlandés Bram Stoker, que es extremadamente original, dramatizada por el joven director Jorge Castro en el Teatro La Plaza (al Centro Larcomar). Después de dos años de trabajo y reflexión, su idea se convirtió en realidad y debe estar feliz. Su adaptación es muy ingeniosa y sorprendente, combinando el terror y el romance, alternando el cuento, los monólogos y los diálogos, músicas, danzas, decoraciones, vestuarios, también imágenes de película y efectos audiovisuales o explicaciones históricas sobre el verdadero Drácula, el siniestro príncipe rumano de Valaquia (hoy el sur de Rumanía) Vlad Țepeş (El Empalador) del siglo XV, muy bien conocido por sus terribles castigos y por sus mórbidas locuras. El actor principal, Miguel Iza, merece también muchos aplausos por su muy buena interpretación. 
Igualmente fui conmovido profundamente de la sensibilidad, el humor fino y el dramatismo de la obra Divina Sarah-Memorias, escrita y estrenada en 1978, de John Murrel-un importante dramaturgo canadiense, nacido en los Estados Unidos-función que se ha podido ver en el Teatro de Lucía, un supernuevo, moderno, íntimo y coqueto teatro de Miraflores (Calle Bellavista no. 512). Se trata del final de la vida (y obra artística, por supuesto) de una actriz francesa de los siglos XIX-XX que hasta hoy está reconocida como la más grande de todas en el mundo entero, Sarah Bernhardt, interpretada por una de las estrellas más brillantes de toda la historia del teatro peruano, Lucía Irurita, que en su remarcable actuación junta serenidad, elegancia y ternura al lado de su noble compañero de escena, el gran actor Hernán Romero, que tiene el papel muy lindo de Georges Pitou, el secretario particular de la diva. Los dos grandes actores logran un espectáculo inolvidable, dentro de una escenografía simple, un poco abstracta pero sugestiva y con una música muy bella. Hay que felicitar también a la directora Ruth Escudero y las dos productoras hermanas Bernasconi: Sandra y Cécica, las hijas de la gran actriz Lucía Irurita, que tienen méritos especiales por el dedicado trabajo en esa obra y por abrir un nuevo teatro en Lima prácticamente sin ayuda de parte de las autoridades.

Finalmente llego a la tercera y última obra: 8 Mujeres, escrita del autor francés Robert Thomas y estrenada en París en 1961, que se presentó al público limeño en el gran y antiguo Teatro Marsano. Las fuertes discusiones, peleas y alusiones de las ocho fieras, la tensión, los chismes, el sarcasmo, la sexualidad y la frivolidad, lo cómico y lo trágico, se mezclan como en una avalancha que te captura y deja mudo, casi inerte al inesperado y macabro final (el suicidio del único personaje masculino, que nunca aparece frente al público). Todo el elenco fue muy bueno, pero la excelencia se notaba sobre todo en una apasionada actriz: Sandra Bernasconi. Ha sido un encanto ver la desenvoltura de esa magnífica actriz que interpreta a límite de la perfección el más complejo y atractivo papel: el de la neurótica Agustina. Es necesario mencionar también la actuación de las jóvenes actrices Alicia Mercado (Caterina) y Masha Chavarri (Zuzón) y la distinción de la destacada Elvira de la Puente (Gaby), igual que la inspiración de siempre del experimentado director Osvaldo Cattone.

Tres obras, tres teatros, tres directores, tres elencos y tres equipos de producción distintos, pero parecidos por su profesionalismo y su pasión por las musas Melpómene y Talía. ¿Qué tienen en común las tres obras? El amor, la necesidad de vivir el sentimiento más noble, más importante y más 
peligroso del mundo, para que al fin nuestras vidas tengan sentido. El amor por el arte teatral y el amor, el deseo de vivir eternamente, de la felicidad y la extrema urgencia de entender la vida, la nuestra y la de los demás.

¿Qué faltas encontré? La falta de interés y colaboración o la indiferencia de las autoridades municipales y gubernamentales para el desarrollo de las artes escénicas; la poca educación artística y a veces la ignorancia de parte del público (especialmente los jóvenes) que no comprende todo, pero se ríe todo el tiempo sin pensar mucho sobre la oportunidad y el mensaje verdadero de las palabras o gestos de los actores (por ejemplo de Drácula), la superficialidad de la mayoría de los comentarios que se pueden oír en el intermedio o al final de las obras y las incómodas sillas de madera del Marsano.

A pesar de todo, he disfrutado muchísimo de cada una de esas obras. Hay otros teatros en Miraflores como el Británico, ICPNA, Larco, el de la Alianza Francesa, que voy a visitar más adelante, pero ahora me provoca ver la gran obra del Nobel peruano, Mario Vargas Llosa, La ciudad y los perros, que está en el Teatro del Centro Cultural de la Pontificia Universidad Católica (aunque no está en Miraflores, sino en San Isidro). 